\title{
Linking spatial patterns of leaf litterfall and soil nutrients in a tropical forest: a neighborhood approach
}

\author{
María Uriarte, ${ }^{1,5}$ Benjamin L. Turner, ${ }^{2}$ Jill Thompson, ${ }^{3,4}$ and Jess K. Zimmerman ${ }^{4}$ \\ ${ }^{1}$ Department of Ecology, Evolution, and Environmental Biology, Columbia University, \\ New York, New York 10027 USA \\ ${ }^{2}$ Smithsonian Tropical Research Institute, Apartado 0843-03092, Balboa, Ancon, Republic of Panama \\ ${ }^{3}$ Centre for Ecology and Hydrology; Bush Estate, Penicuik Midlothian, Scotland EH260QB United Kingdom \\ ${ }^{4}$ Department of Environmental Science, University of Puerto Rico, Box 70377, Rio Piedras, San Juan 00936-8377 Puerto Rico
}

Abstract. Leaf litter represents an important link between tree community composition, forest productivity and biomass, and ecosystem processes. In forests, the spatial distribution of trees and species-specific differences in leaf litter production and quality are likely to cause spatial heterogeneity in nutrient returns to the forest floor and, therefore, in the redistribution of soil nutrients. Using mapped trees and leaf litter data for 12 tree species in a subtropical forest with a well-documented history of land use, we: (1) parameterized spatially explicit models of leaf litter biomass and nutrient deposition; (2) assessed variation in leaf litter inputs across forest areas with different land use legacies; and (3) determined the degree to which the quantity and quality of leaf litter inputs and soil physical characteristics are associated with spatial heterogeneity in soil nutrient ratios $(\mathrm{C}: \mathrm{N}$ and $\mathrm{N}: \mathrm{P})$. The models captured the effects of tree size and location on spatial variation in leaf litterfall $\left(R^{2}=0.31-0.79\right)$. For all 12 focal species, most of the leaf litter fell less than $5 \mathrm{~m}$ away from the source trees, generating finescale spatial heterogeneity in leaf litter inputs. Secondary forest species, which dominate areas in earlier successional stages, had lower leaf litter C:N ratios and produced less litter biomass than old-growth specialists. In contrast, P content and N:P ratios did not vary consistently among successional groups. Interspecific variation in leaf litter quality translated into differences in the quantity and quality $(\mathrm{C}: \mathrm{N})$ of total leaf litter biomass inputs and among areas with different land use histories. Spatial variation in leaf litter C:N inputs was the major factor associated with heterogeneity in soil $\mathrm{C}: \mathrm{N}$ ratios relative to soil physical characteristics. In contrast, spatial variation soil $\mathrm{N}: \mathrm{P}$ was more strongly associated with spatial variation in topography than heterogeneity in leaf litter inputs. The modeling approach presented here can be used to generate prediction surfaces for leaf litter deposition and quality onto the forest floor, a useful tool for understanding soil-vegetation feedbacks. A better understanding of the role of leaf litter inputs from secondary vegetation in restoring soil nutrient stocks will also assist in managing expanding secondary forests in tropical regions.

Key words: inverse modeling; land use; litter quality; Luquillo Forest Dynamics Plot; Puerto Rico; secondary forest; soil-vegetation feedbacks; spatially explicit model; succession.

\section{INTRODUCTION}

Linking species characteristics and ecosystem function has been a pervasive theme in ecology, particularly over the past two decades (Jones and Lawton 1995, Pickett et al. 2001, Wardle 2002, Eviner and Chapin 2003, Hooper et al. 2005). Our growing understanding of the interactions between plant populations, communities, and ecosystems has fundamentally changed our understanding of ecological systems (Naeem 2002, Wardle 2002), and how they respond to management (Pyke and Archer 1991, Ehrenfeld and Toth 1997) and environmental changes (Diaz and Cabido 1997, Chapin 2003).

Manuscript received 18 January 2015; revised 25 February 2015; accepted 2 March 2015. Corresponding Editor: Y. Pan.

55-mail: mu2126@columbia.edu
In forest ecosystems, the dominant ecosystem fluxes (e.g., litterfall, nutrient leaching losses from soil, and nutrient uptake by trees) depend largely upon the identities and size of canopy trees, which have distinctive effects on ecosystem processes at the neighborhood scale, 0-25 m (Binkley and Giardina 1998, Finzi et al. 1998, Gómez-Aparicio and Canham 2008). Although much of the nutrient content in live leaves is translocated prior to senescence and leaf fall (Lodge et al. 1991, Marschner 1999), litterfall is a key pathway for nutrient return to the soil in forests, particularly in tropical ecosystems (Tiessen et al. 1994). Tree species differ in their degree of deciduousness, the nutrient content of their leaves, and the magnitude of nutrient mobilization prior to senescence (van Schaik et al. 1993, Zalamea and Gonzalez 2008). As a result, the spatial distribution of tree species in mixed-forest stands creates heterogeneity in litter and therefore nutrient inputs onto the forest 
floor (Vitousek 1984, Hirabuki 1991, Berendse 1994, Keller et al. 2013).

Spatial variation in the diversity, quantity, and quality (nutrient content and decomposability) of leaf litter inputs is expected to have a marked effect on heterogeneity in soil physical characteristics and nutrient availability (Zinke 1962, Scott and Binkley 1997, Binkley and Giardina 1998, Eviner and Chapin 2003, Hättenschwiler et al. 2005, Gómez-Aparicio and Canham 2008, Keller et al. 2013). Within a given climatic zone, litter quality is the overriding driver of decomposition (Cadish and Giller 1997, Cornelissen et al. 1999, Cornwell et al. 2008). Variation in decomposition rates can be attributed to differences among species in litter characteristics, including leaf toughness, nitrogen $(\mathrm{N})$, phosphorus (P), and lignin concentrations and their consequences for invertebrate and microbial activity and substrate utilization (Pèrez-Harguindeguy et al. 2000, Hättenschwiler et al. 2005, Townsend et al. 2008). Therefore, studies of the neighborhood dynamics of litter deposition offer a particularly powerful vehicle for the integration of community ecology and ecosystem processes.

The majority of research on linkages between tree diversity and soil nutrients has focused on temperate systems (e.g., Finzi et al. 1998), yet tropical rain forests contain hyper-diverse plant communities and play a critical role in global biogeochemical cycles (Field et al. 1998). Interspecific variation in foliar nutrient content has been shown to vary more among species within a tropical forest than across many temperate forest sites (Townsend et al. 2008). How this biogeochemical diversity influences ecosystem properties remains poorly understood. A few studies have examined how individual trees influence ecosystem processes below the canopy (Reed et al. 2008, Wieder et al. 2008, Van Haren et al. 2010, Keller et al. 2013), but a systematic assessment of the relationship between variation in the spatial distribution of multiple tree species and spatial heterogeneity in soil nutrients is lacking.

Successional tropical forests represent an ideal system to study the consequences of spatial heterogeneity in leaf litter deposition on soil nutrients. Light-demanding pioneer species tend to have fast growth rates and produce high-quality leaf litter that decomposes rapidly, leading to high rates of mineralization (Grime 1979, Pastor et al. 1984, Reich et al. 1992, Berendse 1994, Corneliessen et al. 1999, Aerts and Chapin 2000). In contrast, shade-tolerant species that dominate latesuccessional forest stands typically produce low-quality litter, high in lignin and low in N, potentially reducing mineralization rates and soil fertility. Successional shifts in tree species composition may lead to concomitant changes in the chemical and physical characteristics of leaf litter and in litter decomposition rates (Cornelissen et al. 1999, Ostertag et al. 2008, Townsend et al. 2008).

Natural forest regeneration after deforestation has been common throughout the island of Puerto Rico
(Grau et al. 2003), generating a mosaic of stands at different stages of succession that reflects the situation in tropical forest areas across many tropical regions (FAO 2010). Here we examine the influence of forest composition on leaf litter dynamics using spatially explicit information on tree size and species, together with leaf litter deposition and soil nutrient data from the 16-ha Luquillo Forest Dynamics Plot (LFDP) in Puerto Rico. We develop a spatial model of leaf litter deposition to examine the legacies of land use history on leaf litter inputs and soil nutrients. Leaf litter at the site constitutes $\sim 65 \%$ of total litterfall (Vogt et al. 1996). The LFDP has a well-documented history of land use, which drives the spatial distribution of tree species associated with different successional stages (Thompson et al. 2002). This variation in land use allows us to ask the following questions. (1) How do dominant tree species differ in leaf litter biomass production, nutrient chemistry ( $\mathrm{C}, \mathrm{N}$, and $\mathrm{P}$ ), and spatial deposition patterns, and what are the consequences of these differences for spatial heterogeneity in leaf litter inputs? (2) How does spatial variation in tree distributions that reflects the legacy of land use influence the magnitude of nutrient and leaf litter biomass return to the forest soil? (3) To what degree is spatial variation in soil nutrient ratios associated with variation in the quantity and nutrient content of leaf litter inputs relative to soil physical characteristics (rockiness) and land surface topography?

\section{Methods \\ Study site}

The Luquillo Forest Dynamics Plot (LFDP) is a 16ha permanent forest plot (SW corner $18^{\circ} 20^{\prime} \mathrm{N}, 65^{\circ} 49^{\prime}$ W) located near the El Verde Field Station in the Luquillo Mountains of northeastern Puerto Rico. The plot is $500 \mathrm{~m} \mathrm{~N}-\mathrm{S}$ and $320 \mathrm{~m} \mathrm{E}-\mathrm{W}$. Vegetation and topography of this research area are typical of the tabonuco (Dacryodes excelsa) forest zone, except where human disturbance has altered the vegetation (Thompson et al. 2002). The forest is classified as subtropical wet in the Holdridge life zone system (Ewel and Whitmore 1973) and tropical montane in Walsh's (1966) tropical climate system. Rainfall averages $3500 \mathrm{~mm}$ per year. Elevation ranges from 333 to $428 \mathrm{~m}$ above sea level. All of the soils are formed from volcaniclastic sandstone and can be classified into five classes. Zarzal, Cristal, and Prieto are deep clay soils, whereas Coloso and Fluvaquents are formed from alluvium in the stream channels (Soil Survey Staff 1995). Zarzal soils are Oxisols, Cristal soils are Ultisols, Prieto soils are Inceptisols, and Coloso and Fluvaquents are Entisols (Soil Survey Staff 1995; Appendix B: Fig. B1).

The LFDP was established in 1990. Censuses are carried out approximately every five years and follow Center for Tropical Forest Science (CTFS) protocols with a few minor modifications (Condit 1998, Thompson et al. 2002). All free-standing woody stems with dbh $\geq 1 \mathrm{~cm}$ at $130 \mathrm{~cm}$ from the ground (diameter at breast 
TABLE 1. Characteristics of the 12 tree species studied at the Luquillo Forest Dynamics Plot (LFDP) in Puerto Rico.

\begin{tabular}{lllccccc}
\hline \hline \multicolumn{1}{c}{ Species } & Code & \multicolumn{1}{c}{ Family } & $\begin{array}{c}\text { Adult } \\
\text { stems (\%) }\end{array}$ & $\begin{array}{c}\text { Max. } \\
\text { dbh (cm) }\end{array}$ & $\begin{array}{c}\text { Total leaf } \\
\text { litter (\%) }\end{array}$ & Succession & Assoc. \\
\hline Alchornea latifolia & ALCLAT & Euphorbiaceae & 0.89 & 66.0 & 0.77 & secondary & 0 \\
Buchenavia tetraphylla & BUCTET & Combretaceae & 0.94 & 156.6 & 7.86 & late & 0 \\
Casearia arborea & CASARB & Salicaceae & 4.66 & 31.9 & 2.49 & secondary & + \\
Cecropia schreberiana & CECSCH & Cecropiaceae & 8.19 & 43.4 & 5.22 & pioneer & + \\
Dacryodes excelsa & DACEXC & Burseraceae & 6.33 & 85.5 & 19.32 & late & - \\
Guarea guidonia & GUAGUI & Meliaceae & 1.67 & 105.0 & 3.20 & late \\
Inga laurina & INGLAU & Fabaceae & 2.07 & 87.1 & 3.34 & secondary & 0 \\
Manilkara bidentata & MANBID & Sapotaceae & 4.18 & 86.1 & 7.97 & late & - \\
Prestoea montana & PREMON & Arecaceae & 50.27 & 39.2 & 6.18 & secondary & + \\
Schefflera morototoni & SCHMOR & Araliaceae & 2.57 & 55.9 & 1.76 & pioneer & + \\
Sloanea berteriana & SLOBER & Elaeocarpaceae & 2.75 & 91.6 & 5.25 & late \\
Tabebuia heterophylla & TABHET & Bignoniaceae & 1.31 & 70.0 & 2.42 & secondary & - \\
\hline
\end{tabular}

Notes: Adult stems have $\mathrm{dbh} \geq 10 \mathrm{~cm}$; maximum dbh was measured in the 2005 census; for each species, percentage of leaf litter in baskets was calculated as percentage of total biomass for all species beyond the 12 focal species. Association (Assoc.) refers to distribution with respect to human land use ("+" indicates species positively associated with human-disturbed area, "-" refers to a negative association, and "0" refers to no association), determined from Thompson et al. (2002).

height) in the study area are tagged, identified to species, and are measured for dbh. For the analyses presented here we used tree census data from the 2005 and 2011 censuses. Our analyses focused on 12 species that represent variation in life history strategies and successional affinities, and account for $>75 \%$ of adult stems in the plot and $66 \%$ of leaf litter that fell into leaf litter baskets (Tables 1 and 2).

Portions of the area containing the LFDP were used for agriculture and logging before 1934, when the USDA Forest Service purchased the land, effectively ending human use of the area. The northern two-thirds of the plot experienced logging and small-scale farming of various crops interplanted among forest remnants in the early 20th century, whereas the southern one-third experienced only light selective logging in the 1940s. This land-use history is the strongest driver of present-day variation in distribution of species across the plot relative to marked differences in topography, soil, and hurricane damage (García-Montiel 2002, Thompson et al. 2002). The southern area of the LFDP is dominated by species typical of mature tabonuco forest, namely Dacryodes excelsa, Manilkara bidentata, and Sloanea berteriana, and the northern area is currently dominated by the secondary forest species Casearia arborea and the palm Prestoea acuminata var. montana (thereafter Prestoea montana) (Table 1, Fig. 1; see Thompson et al. 2002). For the purposes of this analysis, the LFDP was divided into four distinct areas based on the percent forest canopy cover derived from aerial photos taken in 1936: $1,10-20 \%$; $2,20-50 \%$; $3,50-80 \%$; and $4,80-100 \%$ forest cover (Thompson et al. 2002).

\section{Collection and chemical analyses of leaf litter}

To assess spatial variation in leaf litterfall in the LFDP, a total of 120 mesh baskets were placed every $\sim 8$ $\mathrm{m}$ along established trails and at a distance $8 \mathrm{~m}$ perpendicular to the trail (Fig. 1). The baskets had surface area of $0.5 \mathrm{~m}^{2}$ and were constructed using $1-\mathrm{mm}$ mesh and a frame of PVC tube mounted $80-100 \mathrm{~cm}$

TABle 2. For the 12 study species, $\mathrm{C}, \mathrm{N}$, and $\mathrm{P}$ and their ratios in a composite leaf litter sample from 120 collection baskets, and mean ( $\mathrm{CV}$ in parentheses) contribution to total leaf litter collected in baskets within three land use areas: forest cover in 1936 of $20-50 \%$ ( $n=26$ baskets), $50-80 \%$ ( $n=32$ baskets), and $80-10 \%$ ( $n=62$ baskets).

\begin{tabular}{|c|c|c|c|c|c|c|c|c|c|}
\hline \multirow[b]{2}{*}{ Species code } & \multirow[b]{2}{*}{ Succession } & \multicolumn{3}{|c|}{ Concentration $(\%)$} & \multirow[b]{2}{*}{$\mathrm{C}: \mathrm{N}$} & \multirow[b]{2}{*}{$\mathrm{N}: \mathrm{P}$} & \multicolumn{3}{|c|}{ Litter contribution (\%) by 1936 forest cover } \\
\hline & & $\mathrm{C}$ & $\mathrm{N}$ & $\mathrm{P}$ & & & $20-50 \%$ & $50-80 \%$ & $80-100 \%$ \\
\hline ALCLAT & secondary & 46.92 & 1.22 & 0.046 & 38.4 & 26.5 & $1.52(3.68)$ & $0.077(2.88)$ & $0.77(2.89)$ \\
\hline BUCTET & secondary & 48.14 & 1.14 & 0.034 & 42.2 & 33.5 & $5.51(12.38)$ & $10.24(18.6)$ & $6.71(11.7)$ \\
\hline CASARB & secondary & 50.45 & 1.60 & 0.039 & 31.5 & 41.0 & $1.61(3.27)$ & $7.75(6.7)$ & $0.66(1.68)$ \\
\hline $\mathrm{CECSCH}$ & pioneer & 45.89 & 1.32 & 0.043 & 34.8 & 30.7 & $6.24(12.75)$ & $13.77(19.5)$ & $0.68(2.33)$ \\
\hline DACEXC & late & 44.32 & 0.78 & 0.030 & 56.8 & 26.0 & $12.72(18.32)$ & $2.49(11.02)$ & $30.07(23.08)$ \\
\hline GUAGUI & late & 48.71 & 1.60 & 0.070 & 30.4 & 22.9 & $1.46(4.98)$ & $2.14(4.71)$ & $4.53(7.73)$ \\
\hline INGLAU & secondary & 46.04 & 1.69 & 0.036 & 27.2 & 46.9 & $5.13(8.75)$ & $1.43(2.73)$ & $3.62(6.82)$ \\
\hline MANBID & late & 51.25 & 0.73 & 0.018 & 70.2 & 40.6 & $6.3(13.76)$ & $0.82(2.91)$ & $12.23(14.84)$ \\
\hline PREMON & secondary & 42.33 & 1.94 & 0.079 & 21.8 & 24.6 & $12.22(20.39)$ & $4.96(8.67)$ & $3.93(7.91)$ \\
\hline SCHMOR & pioneer & 49.20 & 1.29 & 0.043 & 38.1 & 30.0 & $0.67(2.06)$ & $4.99(7.92)$ & $0.36(1.10)$ \\
\hline SLOBER & late & 46.78 & 0.96 & 0.021 & 48.7 & 45.7 & 0.37 (1.03) & $7.26(21.42)$ & $4.85(8.64)$ \\
\hline TABHET & secondary & 46.05 & 1.02 & 0.031 & 45.2 & 32.9 & $4.6(11.65)$ & 6.19 (13.97) & $0.05(0.18)$ \\
\hline
\end{tabular}

Notes: See Methods for details and Appendix B: Table B1 for interspecific variation in leaf litter nutrients by land cover class. Successional status for each species was determined from Thompson et al. (2002). 


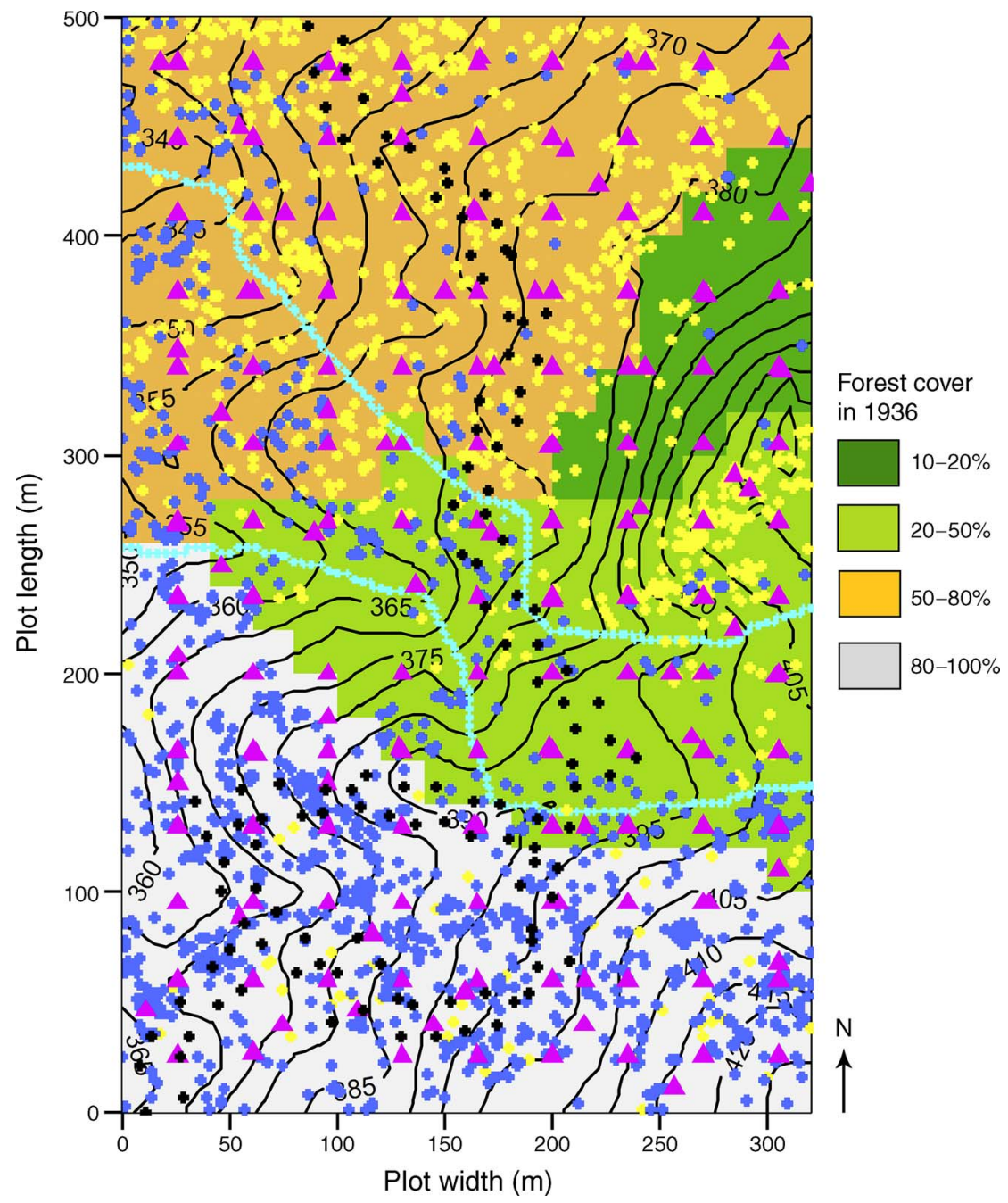

FIG. 1. Land use history and topography of the 16-ha Luquillo Forest Dynamics Plot (LFDP) in Puerto Rico; north-south orientation is parallel to the long axis of the plot. Black dots depict leaf litter collection baskets and magenta triangles show the distribution of soil sampling points. Yellow and blue dots illustrate the distribution of adult trees (dbh $\geq 10 \mathrm{~cm})$ for a secondary (Casearia arborea) and old-growth (Dacryodes excelsa) forest species, respectively.

above the ground. Litterfall was collected from the baskets every two weeks beginning in August 2006 and continuing through the end of August 2007. Leaves of the palm $P$. montana that fell across the litter traps were cut to the area of the basket they intersected when they fell. Leaf litter was sorted to species, oven-dried, and weighed. Individual species from every other biweekly sample (samples collected every two weeks) was ground using a mixer mill (Retsch MM301, Haan, Germany). For each of the 12 focal species, we then combined an equal mass of the ground leaf samples from each of the available biweekly collection dates (not all species produce leaf litter throughout the year), to create a composite sample of leaf material representing the mean annual $\mathrm{C}, \mathrm{N}$, and $\mathrm{P}$ concentration for each species. For any given species, nitrogen and phosphorus concentrations in leaf litter could differ markedly among areas with different land use history or soil, so we also analyzed a composite sample for each species in each of the land cover classes and soil types. Each of the resulting composite (whole plot, by soil type, by land use class) leaf litter samples for each species was analyzed for total $\mathrm{C}, \mathrm{N}$, and $\mathrm{P}$, at the analytic chemistry laboratory of the School of Ecology, University of Georgia. Total $\mathrm{C}$ and $\mathrm{N}$ were determined by combustion analyses and total $\mathrm{P}$ by continuous-flow calorimetric assays after dry ash/acid extractions of the samples.

\section{Collection and chemical analyses of soil}

We quantified spatial variation in soil $\mathrm{C}, \mathrm{N}$, and $\mathrm{P}$ by collecting 183 soil samples in a stratified spatial distribution (based on John et al. 2007) across the whole plot in June 2011 to $10 \mathrm{~cm}$ depth using a $5 \mathrm{~cm}$ diameter soil corer (Fig. 1). Roots were removed and 
each sample was homogenized before air-drying. Dry soil samples were sieved $(<2 \mathrm{~mm})$ and ground to a fine powder in a ball mill. Total $\mathrm{C}$ and $\mathrm{N}$ were determined by automated combustion, gas chromatography, and thermal conductivity detection on a Thermo Flash 1112 Analyzer (Thermo Fisher Scientific, Waltham, Massachusetts, USA). Total soil $\mathrm{P}$ was measured by ignition $\left(550^{\circ} \mathrm{C}, 1 \mathrm{~h}\right)$ and extraction in $1 \mathrm{~mol} / \mathrm{L} \mathrm{H}_{2} \mathrm{SO}_{4}$, with phosphate detection by automated online neutralization and molybdate colorimetry using a Lachat Quikchem 8500 (Hach, Loveland, Colorado, USA).

\section{Spatial heterogeneity in soil C:N and N:P ratios}

We examined the degree to which spatial heterogeneity in soil C:N and N:P ratios are associated with spatial variation of these ratios in leaf litter deposited in the litter traps vs. two abiotic factors. The distribution and composition of the LFDP soil meant that more soil samples were collected in Zarzal (129 out of 183) or Cristal (42 out of 183) soils. Soil characteristics can affect nutrient and carbon stocks and the quantity and quality of leaf litter deposition. However, neither of the two soil nutrient ratios considered $\mathrm{C}: \mathrm{N}(\mathrm{df}=4,178, F=$ $0.189, P=0.94)$ and $\mathrm{N}: \mathrm{P}(\mathrm{df}=4,178, F=2.11, P=0.09)$ differed across soil types. Leaf litter production $(\mathrm{df}=3$, $116, F=1.83, P=0.14$ ) and species-specific leaf litter $\mathrm{C}$, $\mathrm{N}$, and $\mathrm{P}$ were also similar across soil types (Appendix B: Table B1).

We also considered two abiotic predictors of soil C:N and N:P ratios: rock cover and topography in the $5 \times 5 \mathrm{~m}$ area in which a soil sample was collected. A greater percentage of rock cover at our site leads to lower water infiltration and increased runoff and is negatively associated with soil moisture in the plot (M. Uriarte and J. K. Zimmerman, unpublished data) and, potentially, therefore, species composition, litter deposition, and decomposition processes. Topography was used to assign the sampling quadrats to one of two categories: flat areas (valleys and slopes $<15 \%$ slope) were assigned a value of 0 and steep areas (ridges and slopes $>15 \%$ slope) a value of 1 . Steeper slopes in the Luquillo Forest near the LFDP have been associated with greater abundance of litter mats formed by basidiomycete decomposer fungi, and faster decomposition rates (Lodge et al. 2008). Research at the site has also demonstrated that $\mathrm{P}$ tends to accumulate in valleys as a result of weathering on slopes and associated redistribution of soil P to valleys (Mage and Porder 2013).

\section{Statistical analyses}

Question 1. Variation across dominant tree species in leaf litter biomass production, nutrient chemistry $(C, N$, $P)$, and spatial deposition patterns: consequences for spatial heterogeneity in leaf litter inputs.-We used inverse modeling methods similar to those used to model seed dispersal (e.g., Ribbens et al. 1994) to predict leaf litterfall mass as a function of the dbh of individuals of the focal 12 tree species, as source trees, and their distance from the litter traps (Staelens et al. 2004). We used the 2005 LFDP census map because this was the nearest in time to the litter collection from the litter baskets. Specifically, we estimated species-specific litterfall biomass as a function of the number, size, and distance of potential source trees with $\mathrm{dbh}>2.5 \mathrm{~cm}$ within a $25 \mathrm{~m}$ radius of a given collection basket. Leaf litter biomass data were fit using a lognormal dispersal kernel because this functional form has been used successfully in temperate studies and is generally a good fit to the data (Staelens et al. 2004, Gómez-Aparicio and Canham 2008). We calculated a species-specific dispersal kernel which takes the form:

$$
\left.\operatorname{Litterfall}_{k}=\operatorname{TLP} \sum_{i=1}^{n}\left(\frac{\mathrm{dbh}_{i}}{30}\right)^{\alpha} \frac{1}{\eta} e^{-\frac{1}{2}\left(\frac{\ln \left(\text { distance }_{i k} / x_{0}\right.}{x_{b}}\right)}\right)^{2}
$$

where TLP is the estimated total leaf production of a tree with $30 \mathrm{~cm} \mathrm{dbh}, \mathrm{dbh}_{i}$ is the $i$ th tree of $n$ neighbors within a $25 \mathrm{~m}$ radius, distance is the Euclidean distance between leaf litter trap $k$ and tree $i, X_{0}$ is the estimated mean distance at which the maximum amount of litter is deposited (the mode of the deposition kernel), and $X_{b}$ determines the estimated spread (variance) of the kernel. Parameter $\alpha$ captures the allometric relationship between tree size and leaf litter biomass production, and $\eta$ is a normalizer.

All parameters (TLP, $X_{0}, X_{b}$, and $\alpha$ ) were estimated separately for each species using maximum likelihood and simulated annealing (Goffe et al. 1994). Errors approximated a normal distribution in all cases. The fit of the models was evaluated using $R^{2}$ of the regression of observed vs. predicted as a measure of goodness of fit, and slope of the regression as a measure of bias. We used asymptotic two-unit support intervals to assess the strength of evidence for individual estimates of the parameters (Edwards 1992). A more detailed description of the inverse modeling procedure is provided in Appendix A.

To extrapolate results from our analyses to the entire plot and to determine whether our modeling approach generated leaf litter biomass distribution patterns that captured the relative contribution from the 12 species to that collected in the 120 baskets, we simulated leaf litter deposition across the entire plot for each of the 12 focal species. To do so, we used the estimated species-specific kernels together with data on tree species sizes and spatial distribution derived from the 2005 census and species-specific leaf litter $\mathrm{C}, \mathrm{N}$, and $\mathrm{P}$ data. We estimated total inputs of $\mathrm{C}, \mathrm{N}$, and $\mathrm{P}$ by multiplying total leaf litter biomass for each species in each basket by the species' nutrient content specific to the land use in which each source tree was located (Table 2; Appendix B: Table B1). We also calculated a weighted mean nutrient ratio $(\mathrm{C}: \mathrm{N}$ and $\mathrm{N}: \mathrm{P}$ ) by weighing species biomass inputs from each 
of the tree species $(k=1$ through 12$)$ by their land-usespecific leaf litter quality in the land use class in which the source tree was located. For example, C:N at collection basket $b$ was calculated as:

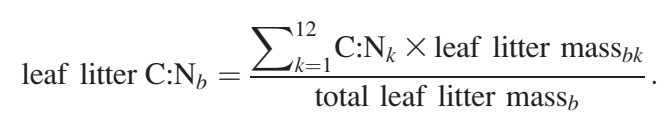

Question 2. Effects of spatial variation in tree distributions across land use categories on magnitude of nutrient and biomass return to the forest soil.-To assess the legacy of land use on the magnitude of biomass and nutrient return to the forest soil via litterfall, we compared species-specific leaf litter biomass and nutrient inputs collected in the baskets in each of the land use areas (Fig. 1). To do so, we followed the same procedure described in Question 1.

We used extrapolated results from simulated leaf litter over the entire plot using methods described in Question 1 , together with species nutrient data, to quantify the patterns of simulated leaf litter biomass and quality across the different land cover classes. Because we did not have any leaf litter baskets in land cover class 1 ( 0 $20 \%$ forest cover), we used leaf litter quality values for land cover class 2 (20-50\% forest cover).

Question 3. Association between spatial variation in soil nutrient ratios and variation in quantity and quality of leaf litter inputs, soil rockiness, and land surface topography.-We examined the degree to which heterogeneity in soil $C: N$ and $N: P$ ratios reflects spatial variation in the $\mathrm{C}: \mathrm{N}$ and $\mathrm{N}: \mathrm{P}$ ratios of the leaf litter deposited. We focused on these metrics because $\mathrm{N}$ and $\mathrm{P}$ vary across species as a result of translocation prior to senescence and these ratios influence decomposition rates and nutrient dynamics after deposition (Aber and Melillo 1980, Manzoni et al. 2010). The N:P ratios may also influence phosphatase activity and therefore $\mathrm{P}$ availability.

To estimate biomass and nutrient inputs from leaf litter deposition for the 183 soil collection locations, we coupled the estimated leaf litter dispersal kernels obtained from the 2005 LFDP tree census map and leaf litter basket collection data with the 2011 LFDP tree census map, because this census was closest to the time of soil sample collection (June 2011). Leaf litter C:N for each soil sampling point was quantified as described in Eq. 2. Because we did not have any leaf litter baskets in land cover class 1 ( $0-20 \%$ forest cover), we used the leaf litter quality values for land cover class 2 (20-50\% forest cover) to predict nutrient inputs for the 13 soil samples collected in land cover class 1 .

After checking for normality of soil $\mathrm{C}: \mathrm{N}$ and $\mathrm{N}: \mathrm{P}$, we conducted a linear regression of soil $\mathrm{C}: \mathrm{N}$ and $\mathrm{N}: \mathrm{P}$ using predicted values from estimated leaf litter inputs (Eq. 2), topography (binary variable), proportion of rock (a continuous variable), and soil type. To facilitate interpretation and comparison of importance of individual covariates, we standardized covariates by sub- tracting the mean and dividing by two standard deviations (Gelman and Hill 2009). All analyses were conducted using $\mathrm{R}$ statistical software version 3.01 ( $\mathrm{R}$ Core Team 2013).

\section{RESUlts}

Variation across dominant tree species in leaf litter biomass production, nutrient chemistry $(C, N$, and $P)$, and spatial deposition patterns

Leaf litter of the 12 focal species varied substantially in concentrations of $\mathrm{C}, \mathrm{N}$, and $\mathrm{P}$ and, consequently, in $\mathrm{C}: \mathrm{N}$ and $\mathrm{N}: \mathrm{P}$ ratios (Table 2). As expected, pioneer and early-successional species had higher $\mathrm{N}$ concentrations and lower $\mathrm{C}: \mathrm{N}$ ratios than late-successional species. Differences in $\mathrm{P}$ concentrations and $\mathrm{N}: \mathrm{P}$ ratios were not consistent among successional groups (Table 2). Although there was some species-specific variation in leaf litter C:N and N:P across land use classes and soil types, these were relatively minor when compared with large interspecific variation between late-successional species and secondary or pioneer species (Appendix B: Tables $\mathrm{B} 1$ and $\mathrm{B} 2$ ).

Annual leaf litter biomass deposited by the 12 study species over the course of the one-year sampling period in the collection baskets ranged from 50.72 to 1053.82 $\mathrm{g} \cdot \mathrm{m}^{-2} \cdot \mathrm{yr}^{-1}\left(392.14 \pm 1.77 \mathrm{~g} \cdot \mathrm{m}^{-2} \cdot \mathrm{yr}^{-1}\right.$, mean $\left.\pm \mathrm{SE}\right)$. The spatial distribution of leaf nutrient inputs into these baskets was also highly variable, ranging from 24.14 to $519.04 \mathrm{~g} \mathrm{C} \cdot \mathrm{m}^{-2} \cdot \mathrm{yr}^{-1}\left(188.85 \pm 0.81 \mathrm{~g} \mathrm{C} \cdot \mathrm{m}^{-2} \cdot \mathrm{yr}^{-1}\right), 0.70$ to $12.27 \mathrm{~g} \mathrm{~N} \cdot \mathrm{m}^{-2} \cdot \mathrm{yr}^{-1}\left(4.55 \pm 0.02 \mathrm{~g} \mathrm{~N} \cdot \mathrm{m}^{-2} \cdot \mathrm{yr}^{-1}\right)$, and 0.02 to $0.51 \mathrm{~g} \mathrm{P} \cdot \mathrm{m}^{-2} \cdot \mathrm{yr}^{-1}\left(0.14 \pm 0.0003 \mathrm{~g} \mathrm{P} \cdot \mathrm{m}^{-2} \cdot \mathrm{yr}^{-1}\right)$. Mean weighted $\mathrm{C}: \mathrm{N}$ ratios, derived from relative biomass contributions of each of the 12 focal species, ranged across the baskets from 26.97 to 65.21 (44.35 0.90 , mean $\pm \mathrm{SE}$ ) and $\mathrm{N}: \mathrm{P}$ ratios ranged between 20.56 and $41.02(34.68 \pm 0.13)$.

The models of leaf litter dispersal exhibited a moderate to strong fit to the data, accounting, on average, for $59 \%$ of observed variation in leaf litter deposition and ranging from a low of $31 \%$ of observed variation for the palm ( $P$. montana) to a high of $79 \%$ for the pioneer Schefflera morototoni (Appendix A: Table A1). The low fit for the palm probably results from the fact that the palm fronds fall very close to the palm stem and it is difficult to catch such long, heavy fronds in the small litter traps. Separate simulations of leaf litter across the entire plot for each of the 12 focal species showed that the inverse modeling approach generated leaf litter biomass that captured the relative contribution from the 12 species to that collected in the 120 baskets (Appendix A: Table A2). The two species that diverged from this pattern accounted for only $1.16 \%$ (Alchornea latifolia) and $3.67 \%$ (S. morototoni) of observed total leaf litter inputs.

Tree species in the LFDP display great variation in both the total amount of litter that they produce (parameter TPL in Eq. 1) and the way in which leaf litter production varies with tree size (parameter $\alpha$ in Eq. 


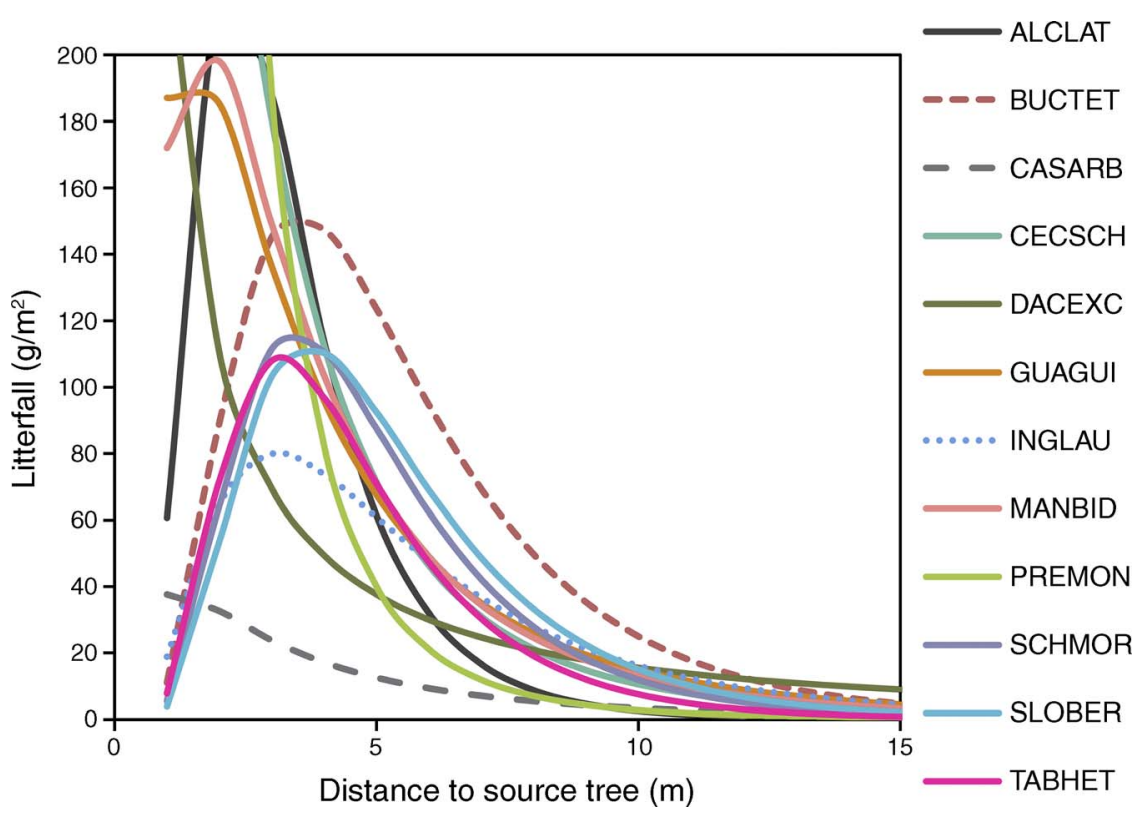

FIG. 2. Leaf litter dispersal kernels for a tree with $\mathrm{dbh}=30 \mathrm{~cm}$ for each of the 12 focal species included in the analyses, parameterized using Eq. 1. Species codes are provided in Table 1.

1; see Appendix A: Table A1). For example, a $30 \mathrm{~cm} \mathrm{dbh}$ D. excelsa produced $38755.53 \mathrm{~g}$ litter/yr, with production increasing in an almost quadratic fashion with tree size. In contrast, a $30 \mathrm{~cm} \mathrm{dbh} C$. arborea tree is estimated to produce only $2533.63 \mathrm{~g}$ litter/yr, with production decreasing for larger trees. The shape of the kernel was also highly variable, with some tree species dropping the majority of leaves within a tight radius from the source (e.g., P. montana, parameter $X_{b}=0.86 \mathrm{~m}$ ) and others having a more diffuse litter shadow (e.g., D. excelsa, $X_{b}$ $=2.77 \mathrm{~m}$ ); see Fig. 2. The mode of the dispersal kernel, i.e., the distance from the source tree at which leaf litter was highest, ranged from $0.01 \mathrm{~m}$ to almost $3.67 \mathrm{~m}$, and the variance ranged from $0.50 \mathrm{~m}$ to $2.77 \mathrm{~m}$ (Fig. 2; Appendix A: Table A1). There were no consistent patterns in overall leaf production or the shape of the kernels for species within a given successional group.

We used the estimated species-specific kernels together with data collected in the 2005 census on tree species sizes and spatial distribution and species-specific leaf litter $\mathrm{C}, \mathrm{N}$, and $\mathrm{P}$ data to extrapolate leaf litter biomass and nutrients across the entire plot. Variation in tree species distributions and the fact that most of the leaf litter fell less than $5 \mathrm{~m}$ away from the source trees, led to substantial fine-scale spatial heterogeneity in leaf quantity and quality of leaf litter inputs (Fig. 3). Average simulated leaf litter deposition across the plot was highly variable, ranging from 20.61 to $10936.73 \mathrm{~g} \cdot \mathrm{m}^{2} \cdot \mathrm{yr}^{1}$. On average, however, simulated leaf litter biomass was comparable to average amounts collected in the baskets (simulated deposition $401.92 \pm 0.65 \mathrm{~g} \cdot \mathrm{m}^{-2} \cdot \mathrm{yr}^{-1}$, mean \pm $\mathrm{SE})$. The simulated spatial distribution of leaf nutrients inputs was also highly variable, ranging from 0.24 to
$85.79 \mathrm{~g} \mathrm{~N} \cdot \mathrm{m}^{-2} \cdot \mathrm{yr}^{-1}\left(4.73 \pm 0.67 \mathrm{~g} \mathrm{~N} \cdot \mathrm{m}^{-2} \cdot \mathrm{yr}^{-1}\right)$, and 0.07 to $0.32 \mathrm{~g} \mathrm{P} \cdot \mathrm{m}^{-2} \cdot \mathrm{yr}^{-1}\left(0.16 \pm 0.022 \mathrm{~g} \mathrm{P} \cdot \mathrm{m}^{-2} \cdot \mathrm{yr}^{-1}\right)$. Composite $\mathrm{C}: \mathrm{N}$ ratios of leaf litter inputs across the plot ranged from 23.09 to 67.39 (42.58 \pm 0.02 , mean \pm $\mathrm{SE})$ and $\mathrm{N}: \mathrm{P}$ from 23.17 to 45.23 (31.47 \pm 0.01$)$; see Fig. $3 \mathrm{~B}$.

\section{Effects of spatial variation in tree species distributions across land use categories on magnitude of leaf litter biomass and nutrient return to forest soil}

Differences in the spatial distribution of species with respect to land use history were reflected in variation in leaf litter biomass inputs across the 120 leaf litter collection baskets, total leaf litter $\mathrm{C}, \mathrm{N}$, and $\mathrm{C}: \mathrm{N}$ ratios (Tables 1 and 2; Appendix B: Table B1). Both biomass and total $\mathrm{C}$ leaf litter inputs were greater in areas with more than $50 \%$ forest cover in 1936. Biomass inputs ranged from $313.92 \mathrm{~g} \cdot \mathrm{m}^{-2} \cdot \mathrm{yr}^{-1}$ with $20-50 \%$ forest cover in 1936 , to $419.14 \mathrm{~g} \cdot \mathrm{m}^{-2} \cdot \mathrm{yr}^{-1}$ in areas with more than $80 \%$ forest cover. Differences in mean speciesweighted leaf litter $\mathrm{C}: \mathrm{N}$ ratios among land cover classes were also marked, with higher C:N ratios in areas with $80-100 \%$ forest cover in 1936 relative to areas with 20 $80 \%$ cover (Table 3). No consistent differences were observed for $\mathrm{N}$.

Simulated leaf litter inputs exhibited patterns that were largely parallel to those observed in baskets across different land cover classes (Table 4). Nevertheless, there were some marked differences. Observed leaf litter biomass and carbon inputs into baskets located in land cover area 3 (50-80\% forest cover in 1936) was almost one-third higher than simulated quantities. Simulated and observed values for composite leaf litter C:N also 

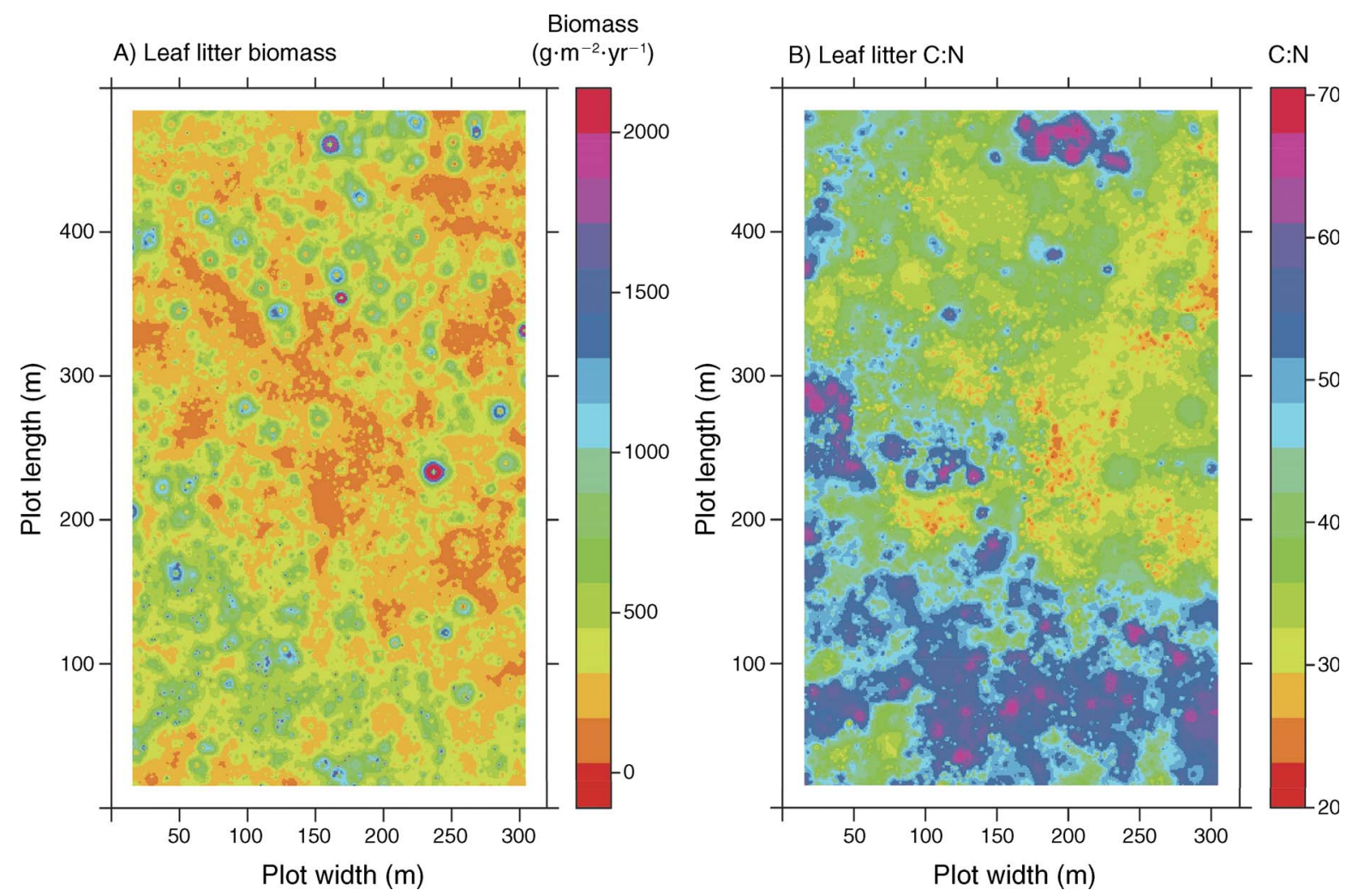

FIG. 3. Predicted spatial distribution of leaf litter (A) biomass and (B) weighted C:N in the LFDP based on the 2005 tree census and estimated dispersal kernels (Appendix A: Table A1). Data within $15 \mathrm{~m}$ of the plot edge are omitted because the majority of leaf litter falls within this distance of source trees, but a complete set of source trees is lacking.

exhibited similar differences (Table 4). There were no consistent patterns across land use classes in $\mathrm{N}$ and $\mathrm{P}$ inputs or in N:P ratios.

\section{Association between spatial variation in soil nutrient} ratios and variation in the quantity and quality of leaf litter inputs, soil rockiness, and topography

We used the estimated species-specific kernels, together with data collected in the 2011 census on tree species sizes and spatial distribution and species-specific leaf litter $\mathrm{C}, \mathrm{N}$, and $\mathrm{P}$ data to extrapolate mean weight leaf litter $\mathrm{C}: \mathrm{N}$ and $\mathrm{N}: \mathrm{P}$ for the points at which soil samples were collected. This allowed us to associate soil and leaf litter quality.

Our model of the factors that are associated with spatial variation in soil C:N accounted for $27 \%$ of observed variation (Table 5). Soil C:N ratios were positively associated with simulated leaf litter $\mathrm{C}: \mathrm{N}$ and the percentage of rock (Table 5). Among factors included in the regression, spatial heterogeneity in simulated leaf litter $\mathrm{C}: \mathrm{N}$ was the most important predictor of soil $\mathrm{C}: \mathrm{N}$ ratios. The soil $\mathrm{N}: \mathrm{P}$ model captured $16 \%$ of observed variation, with most of the variation attributable to spatial heterogeneity in simulated leaf litter N:P and topography (Table 5). Overall,

TABLe 3. Mean (CV in parenthesis) leaf litter biomass and C, N, and P deposition and weighted means (see Eq. 2) and CVs of leaf litter C:N and N:P ratios from the 12 study species in 120 collection baskets in four land use areas in the LFDP.

\begin{tabular}{|c|c|c|c|c|c|c|c|}
\hline \multirow{2}{*}{$\begin{array}{c}\text { Forest cover, } \\
1936\end{array}$} & \multirow{2}{*}{$\begin{array}{c}\text { No. } \\
\text { samples }\end{array}$} & \multicolumn{4}{|c|}{ Mass in leaf litter $\left(\mathrm{g} \cdot \mathrm{m}^{-2} \cdot \mathrm{yr}^{-1}\right)$} & \multicolumn{2}{|c|}{ Ratios in litter } \\
\hline & & Biomass & $\mathrm{C}$ & $\mathrm{N}$ & $\mathrm{P}$ & $\mathrm{C}: \mathrm{N}$ & $\mathrm{N}: \mathrm{P}$ \\
\hline $10-20 \%$ & 0 & NA & NA & NA & NA & NA & NA \\
\hline $20-50 \%$ & 26 & $313.92^{\mathrm{a}}(0.75)$ & $144.23^{\mathrm{a}}(0.70)$ & $4.02^{\mathrm{a}}(0.84)$ & $0.061^{\mathrm{a}}(0.99)$ & $42.03^{\mathrm{a}}(0.25)$ & $31.93^{\mathrm{a}}(0.15)$ \\
\hline $50-80 \%$ & 32 & $403.15^{\mathrm{b}}(0.61)$ & $189.44^{\mathrm{b}}(0.60)$ & $5.09^{\mathrm{a}}(0.56)$ & $0.078^{\mathrm{a}}(0.58)$ & $37.14^{\mathrm{a}}(0.17)$ & $33.55^{\mathrm{a}}(0.12)$ \\
\hline $80-100 \%$ & 62 & $419.14^{\mathrm{b}}(0.43)$ & $194.73^{\mathrm{b}}(0.43)$ & $4.24^{\mathrm{a}}(0.47)$ & $0.072^{\mathrm{a}}(0.49)$ & $50.63^{\mathrm{b}}(0.15)$ & $31.88^{\mathrm{a}}(0.13)$ \\
\hline
\end{tabular}

Notes: Different superscript letters indicate that the means were significantly different at $P=0.05$ (ANOVA plus Bonferroni pairwise tests). NA means that data were not available. 
TABLE 4. From simulated leaf litter deposition (using the 2005 census) for the 12 study species in areas with different land use legacies in the LFDP, mean (CV in parenthesis) leaf litter biomass, C, N, and P deposition and weighted means (see Eq. 2) and CVs of leaf litter C:N and N:P ratios.

\begin{tabular}{|c|c|c|c|c|c|c|}
\hline \multirow{2}{*}{$\begin{array}{c}\text { Forest cover, } \\
1936\end{array}$} & \multicolumn{4}{|c|}{ Mass in leaf litter $\left(\mathrm{g} \cdot \mathrm{m}^{-2} \cdot \mathrm{yr}^{-1}\right)$} & \multicolumn{2}{|c|}{ Ratios in litter } \\
\hline & Biomass & $\mathrm{C}$ & $\mathrm{N}$ & $\mathrm{P}$ & $\mathrm{C}: \mathrm{N}$ & $\mathrm{N}: \mathrm{P}$ \\
\hline $10-20 \%$ & $348.18(0.59)$ & $164.16(0.60)$ & $4.65(0.55)$ & $0.14(0.55)$ & $36.45(0.12)$ & $32.92(0.08)$ \\
\hline $20-50 \%$ & $318.97(0.62)$ & $148.16(0.64)$ & $4.05(0.57)$ & $0.13(0.57)$ & $39.69(0.22)$ & $31.67(0.09)$ \\
\hline $50-80 \%$ & $308.79(0.45)$ & $141.44(0.45)$ & $3.21(0.39)$ & $0.10(0.42)$ & $47.61(0.23)$ & $32.18(0.08)$ \\
\hline $80-100 \%$ & $457.91(0.47)$ & $212.66(0.52)$ & $4.87(0.46)$ & $0.17(0.47)$ & $48.01(0.16)$ & $30.52(0.10)$ \\
\hline
\end{tabular}

Note: Simulated data within $15 \mathrm{~m}$ of the plot edge are omitted because the majority of leaf litter falls within this distance of source trees but a complete set of source trees is lacking.

soil N:P values were greater with high leaf litter N:P and in steeper, relative to flatter, areas (Table 5).

\section{Discussion}

Variation across dominant tree species in leaf litter biomass production, nutrient chemistry $(C, N$, and $P)$, and spatial deposition patterns: consequences for spatial heterogeneity in leaf litter inputs

Dominant tree species at the site differed substantially in the quantity and quality of leaf litter production. Consistent with previous studies elsewhere (Grime 1979, Pastor et al. 1984, Reich et al. 1992, Berendse 1994, Corneliessen et al. 1999, Aerts and Chapin 2000), lightdemanding pioneer species produced high-quality leaf litter high in $\mathrm{N}$, whereas leaf litter of shade-tolerant species was low in $\mathrm{N}$, with high $\mathrm{C}: \mathrm{N}$ ratios. Our analyses also demonstrate that most leaf litter for the tree species included in our study falls at relatively short distances from the source tree $(<5 \mathrm{~m})$, with only a small percentage of leaf litter deposited farther than $10 \mathrm{~m}$ away from the source tree. Short dispersal distances, coupled with interspecific differences in the quantity and quality of leaf litter inputs, led to substantial fine-scale spatial heterogeneity in the quantity and quality of leaf litter inputs across the plot.

These findings, together with results from other studies of leaf litter impacts on forests, suggest potential local neighborhood effects of leaf litter on seed germination and seedling establishment, growth, and survival (Guzmán-Grajales and Walker 1991, Walker et al. 2003). These litter effects might operate through changing the physical environment for seeds and seedlings, a particularly important effect for smallseeded species (e.g., Molofsky and Augspurger 1992,
Vazquez-Yanes and Orozco-Segovia 1992, Muscarella et al. 2013), nutrient availability (Gómez-Aparicio and Canham 2008), soil structure (Ostertag et al. 2008), and impacts of pathogens and herbivores via Janzen-Connell effects (Benitez-Malvido and Kossmann-Ferraz 1999).

The neighborhood approach presented here shows great potential for understanding the effects of tree species composition on spatial variation in the quantity and quality of leaf litter inputs and return of nutrients to soil in tropical forests and the potential changes that might occur as secondary forests regenerate and develop over time. The goodness of fit of the models suggests that the method captures the influence of tree size and proximity on leaf litter deposition for the majority of species, with $R^{2}$ values comparable to those observed in temperate forests (Staelens et al. 2003, Gómez-Aparicio and Canham 2008). An additional benefit of this method relative to whole-averaged plot-based analyses of leaf litter production, which typically only take into account tree size or basal area (e.g., Hirabuki 1991), is that our method disentangles the effects of tree size and location (i.e., distance to litter collection site) on spatial variation in leaf litter inputs from individual species. Together with data on tree species variation in leaf nutrients or other leaf functional characteristics (e.g., lignin content), this information can be used to generate prediction surfaces for leaf litter deposition onto the forest floor, a powerful tool for understanding soil-vegetation feedbacks at relevant spatial scales (Gómez-Aparicio and Canham 2008).

\section{Effects of spatial variation in tree distributions across land use categories on magnitude of nutrient and biomass return to the forest soil}

Previous research at the site has demonstrated that areas with stronger legacies of land use contain a higher

TABLE 5. Results of linear regression of soil C:N and N:P $(n=183)$, with standardized coefficients for the effect of predicted ratios in leaf litter $\mathrm{C}: \mathrm{N}$ and $\mathrm{N}: \mathrm{P}$, topography, and rock cover.

\begin{tabular}{ccccr}
\hline \hline Response variable & Adj. $R^{2}$ & Predicted leaf litter ratio & Topography & Rock cover $(\%)$ \\
\hline Soil C:N & 0.27 & $1.98(0.29)^{* * * *}$ & $-0.56(0.43)$ & $0.48(0.29)^{*}$ \\
Soil N:P & 0.16 & $2.96(0.62)^{* * * *}$ & $3.64(1.04)^{* * * *}$ & $-0.25(0.62)$
\end{tabular}

Notes: Standardizations allow for direct comparison of the importance of each covariate for a given response variable (Gelman and Hill 2009). Significance is indicated by $* P<0.05$; **** $P=$ 0.0001 . 
number of pioneer and secondary tree species and lower basal area (Thompson et al. 2002, Uriarte et al. 2009). Our data show that species prevalent in areas with highintensity past land use history generate litter with higher $\mathrm{N}$ and lower $\mathrm{C}: \mathrm{N}$ ratios than species associated with areas of less intense human land use. In accordance with our expectation, both observations from baskets and simulated leaf litter deposition across the plot uncovered differences in species-weighted mean leaf litter $C: N$ across land use classes, with greater values in areas that had more than $80 \%$ land cover in 1936, which are dominated by $D$. excelsa and $M$. bidentata. We also found greater leaf litter biomass and $\mathrm{C}$ inputs in these same areas. These differences can be attributed to dominance of late-successional species in areas with low-intensity land use, because these species account for a greater proportion of total aboveground biomass in this section of the plot (Table 1) (Zou et al. 1995, Zalamea and González 2008). These results support the notion that successional shifts in tree species composition can lead to changes in the chemical and physical characteristics of leaf litter and, potentially in plantvegetation dynamics (Cornelissen et al. 1999, XulucTolosa et al. 2003, Ostertag et al. 2008, Townsend et al. 2008).

\section{Association between spatial variation in soil nutrient ratios and variation in quantity and quality of leaf litter inputs, soil rockiness, and land surface topography}

Spatial heterogeneity in the quality of leaf litter inputs across the plot was strongly associated with the spatial variation in soil $\mathrm{C}: \mathrm{N}$ and $\mathrm{N}: \mathrm{P}$ ratios, suggesting that interspecific differences in leaf litter production and quality are a major factor underlying observed variation in soil nutrients. Although our data show some intraspecific variation in leaf litter nitrogen and phosphorus among areas with different land use history and soil type, these differences were relatively minor when compared with interspecific differences. These findings lend support to a number of studies in temperate and tropical forests (Pastor et al. 1984, Binkley and Giardina 1998, Finzi and Canham 1998, Xuluc-Tolosa et al. 2003, Gómez-Aparicio and Canham 2008, Reed et al. 2008), demonstrating links between leaf litter inputs, soil nutrient pools, and ecosystem processes (e.g., decomposition and $\mathrm{N}$ mineralization). The majority of these studies, however, focused on isolating effects of one or a few tree species on soil processes. In contrast, our study examines the association of soil nutrient pools and leaf litter inputs for all the dominant species in a community. Predicting the combined ecosystem effects of species in mixtures on ecosystem process (e.g., $\mathrm{N}$ mineralization), however, represents a real challenge because the mechanisms behind individual case studies offer few generalizations. When species effects are nonadditive, nonspatial models will either overestimate (antagonistic) or underestimate (synergistic) average resource conditions within a stand (Finzi and Canham 1998). Although some progress has been made in this area, our understanding of nonadditive effects is limited, particularly in forest ecosystems (Eviner and Chapin 2003).

Legacy effects of Hurricane Hugo in 1989 and Georges in 1998 may also account for some of the observed relationship between soil $\mathrm{C}: \mathrm{N}$ and leaf litter $\mathrm{C}: \mathrm{N}$. Secondary forest species prevalent in areas with a history of more intense human land also experienced higher rates of hurricane damage at the site (Zimmerman et al. 1994, Uriarte et al. 2009). As a result, inputs of woody debris in areas of high-intensity land use are likely to have been greater than those to areas with lowintensity land use. Approximately $85 \%$ of hurricanegenerated debris was woody debris $>5 \mathrm{~cm}$ in diameter which may have increased soil $\mathrm{N}$ availability and aboveground productivity by as much as $40 \%$ (Zimmerman et al. 1995). Simulations of an ecosystem model (CENTURY) calibrated for this forest indicated that $\mathrm{N}$ immobilization by decaying wood can influence soil nutrient dynamics for almost 30 years following the hurricane (Sanford et al. 1991, Zimmerman et al. 1995). Legacies of hurricane events may have contributed to lower $\mathrm{C}: \mathrm{N}$ ratios in areas dominated by secondary forest species.

Several mechanisms may account for the observed positive relationship between soil $\mathrm{C}: \mathrm{N}$ and rockiness of the soil. Soil moisture tends to be low in rocky areas, possibly leading to slower decomposition rates and higher $\mathrm{C}: \mathrm{N}$ ratios. Rockier areas are disproportionately distributed in areas with a history of low-intensity land use (Thompson et al. 2002), potentially because these areas were less amenable to cultivation and this reinforced the effects of land use legacies on tree species distributions. Shallow slopes in this forest are also subject to overland flow during the torrential rains that accompany frequent tropical storm activity (Weaver et al. 1987). Research at the Luquillo Forest examining the factors that influence soil organic content (SOC) found that ridge soils were generally deeper and higher in SOC than shallower soils in valleys (Johnson et al. 2011).

High leaf litter N:P was also associated with high soil $\mathrm{N}: \mathrm{P}$. However, the most important factor accounting for spatial heterogeneity in soil N:P was topography, with greater N:P values in steeper relative to flatter areas. Previous research in the Luquillo Forest has demonstrated that $\mathrm{P}$ tends to accumulate in valleys as a result of redistribution of fine soil materials and associated phosphorus from slopes and ridges to valley floors and alluvial soils, possibly accounting for our results (Mage and Porder 2013). The watersheds at the study site receive high rates of rainfall $(3-4 \mathrm{~m} / \mathrm{yr})$, resulting in high rates of weathering, particularly on steep slopes and ridges (White et al. 1998).

\section{Conclusions}

Our study supports the notion that human land use may modify existing biotic-environment relationships (Foster et al. 1998). Legacies of human land use on tree 
community composition and, therefore, on leaf litter quantity and quality will influence nutrient return to the soil, and thus available soil nutrients. Many tropical forests of the future will be secondary forest developing after human disturbance (Chazdon 2003). The rate and degree of secondary forest recovery is often constrained by soil fertility, with more intense land uses requiring longer time to recovery or, in some cases, direct restoration interventions (Ewel 1976, Guariguata and Ostertag 2001, Chinea 2002, Chazdon 2003). Forest planting or management to promote natural development of secondary forests will require a better understanding of the relative roles that species-specific litter inputs play in restoring soil physical structure and nutrient stocks to speed the rate of soil and forest recovery and to maximize carbon storage.

\section{ACKNOWLEDGMENTS}

We thank John Bithorn, Samuel Matta, Dan Flynn, and Tamar Cooper for assistance in collecting and processing leaf litter samples and Deborah J. Lodge for useful suggestions on the manuscript. This work was supported by NSF grants DEB0516066 and DEB-0614659, which supported the tree censuses and litter collection, respectively. Additional support provided by the Smithsonian Tropical Research Institute and grants (DEB-0620910 and DEB-0218039) from NSF to the University of Puerto Rico working with the International Institute of Tropical Forestry (USDA Forest Service), for the Luquillo Long-Term Ecological Research Program. The U.S. Forest Service and the University of Puerto Rico provided additional support. Soil collection and analysis was funded by the Smithsonian Institution Geo-Observatories program and we thank Chris Nytch and Tania Romero for assistance in the field, and Dayana Agudo, Aleksandra Bielnicka, and Paola Escobar for laboratory support.

\section{Literature Cited}

Aber, J. D., and J. M. Melillo. 1980. Litter decomposition: measuring state of decay and percent transfer into forest soils. Canadian Journal of Botany 158:416-421.

Aerts, R., and F. S. Chapin. 2000. The mineral nutrition of wild plants revisited: A re-evaluation of processes and patterns. Advances in Ecological Research 30:1-67.

Benitez-Malvido, J., and I. D. Kossmann-Ferraz. 1999. Litter cover variability affects seedling performance and herbivory. Biotropica 31:598-606.

Berendse, F. 1994. Competition between plant populations at low and high nutrient supply. Oikos 71:253-260.

Binkley, D., and C. Giardina. 1998. Why do tree species affect soils? The warp and woof of tree-soil interactions. Biogeochemistry 42:89-106.

Cadish, G., and K. E. Giller. 1997. Driven by nature: plant litter quality and decomposition. CAB International, Wallingford, UK.

Chapin, F. S., III. 2003. Effects of plant traits on ecosystem and regional processes: a conceptual framework for predicting the consequences of global change. Annals of Botany 91:455463.

Chazdon, R. L. 2003. Tropical forest recovery: legacies of human impact and natural disturbance. Perspectives in Plant Ecology, Evolution and Systematics 6:51-71.

Chinea, J. D. 2002. Tropical forest succession on abandoned farms in the Humacao municipality of eastern Puerto Rico. Forest Ecology and Management 167:195-207.

Condit, R. 1998. Tropical forest census plots: methods and results from Barro Colorado Island, Panama, and a comparison with other plots. Springer-Verlag, Berlin, Germany.

Cornelissen, J. H. C., N. Pèrez-Harguindeguy, S. Diaz, J. P. Grime, B. Marzano, M. Cabido, F. Vendramini, and B. Cerabolini. 1999. Leaf structure and defense control litter decomposition rate across species and life forms in regional floras on two continents. New Phytologist 143:191-200.

Cornwell, W. K., et al. 2008. Plant species traits are the predominant control on litter decomposition rates within biomes worldwide. Ecology Letters 11:1065-1071.

Diaz, S., and M. Cabido. 1997. Plant functional types and ecosystem function in relation to global change. Journal of Vegetation Science 8:463-474.

Edwards, A. W. F. 1992. Likelihood. John Hopkins University Press, Baltimore, Maryland, USA.

Ehrenfeld, J. G., and L. A. Toth. 1997. Restoration ecology and the ecosystem perspective. Restoration Ecology 5:307-317.

Eviner, V. T., and F. S. Chapin, III. 2003. Functional matrix: a conceptual framework for predicting multiple plant effects on ecosystem processes. Annual Review of Ecology, Evolution, and Systematics 34:455-485.

Ewel, J. J. 1976. Litter fall and leaf decomposition in a tropical forest succession in eastern Guatemala. Journal of Ecology 64:293-307.

Ewel, J. J., and J. L. Whitmore. 1973. The ecological life zones of Puerto Rico and the United States Virgin Islands. Forest Service Research Papers ITF-18. International Institute of Tropical Forestry, Rio Piedras, Puerto Rico, USA.

FAO. 2010. Global forest resources assessment 2010. Food and Agricultural Organization of the United Nations, Rome, Italy.

Finzi, A. C., N. van Breemen, and C. D. Canham. 1998. Canopy tree-soil interactions within temperate forests: tree species effects on carbon and nitrogen. Ecological Applications 8:440-446.

Finzi, A. F., and C. D. Canham. 1998. Synergistic effects of litter mixtures on net $\mathrm{N}$ mineralization in a southern New England forest. Forest Ecology and Management 105:135148.

Foster, D. R., G. Motzkin, and B. Slater. 1998. Land use history as long-term, broad scale disturbance: regional forest dynamics in central New England. Ecosystems 1:96-119.

García-Montiel, D. C. 2002. El legado de la actividad humana en los bosques neotropicales contemporáneos. Pages 97-116 in M. Guariguata and G. Kattan, editors. Ecología y Conservación de Bosques Neotropicales. Libro Universitario Regional, Cartago, Costa Rica.

Gelman, A., and J. Hill. 2009. Data analysis using regression and multilevel/hierarchical models. Cambridge University Press, Cambridge, UK.

Goffe, W. L., G. D. Ferrier, and J. Rogers. 1994. Global optimization of statistical functions with simulated annealing. Journal of Econometrics 60:65-99.

Gómez-Aparicio, L., and C. D. Canham. 2008. Neighborhood models of the effects of invasive tree species on ecosystem processes. Ecological Monographs 78:69-86.

Grau, H. R., T. M. Aide, J. K. Zimmerman, J. R. Thomlinson, E. Helmer, and X. Zou. 2003. The ecological consequences of socioeconomic and land use changes in post-agriculture Puerto Rico. BioScience 53:1159-1168.

Grime, P. G. 1979. Plant strategies and vegetation processes. Wiley, New York, New York, USA.

Guariguata, M. R., and R. Ostertag. 2001. Neotropical secondary forest succession: changes in structural and functional characteristics. Forest Ecology and Management 148:185-206

Guzmán-Grajales, S., and L. R. Walker. 1991. Differential seedling responses to litter after hurricane Hugo in the Luquillo Experimental Forest in Puerto Rico. Biotropica 23:407-413. 
Hättenschwiler, S., A. V. Tiunov, and S. Scheu. 2005. Biodiversity and litter decomposition in terrestrial ecosystems. Annual Review of Ecology, Evolution, and Systematics 36:191-218.

Hirabuki, Y. 1991. Heterogeneous dispersal of tree litterfall corresponding with patchy canopy structure in a temperate mixed forest. Plant Ecology 94:69-79.

Hooper, D. U., et al. 2005. Effects of biodiversity on ecosystem functioning: a consensus of current knowledge. Ecological Monographs 75:3-35.

John, R., et al. 2007. Soil nutrients influence spatial distributions of tropical tree species. Proceedings of the National Academy of Sciences USA 104:864-869.

Johnson, K. D., F. N. Scatena, and W. L. Silver. 2011. Atypical soil carbon distribution across a tropical steepland forest catena. Catena 87:391-397.

Jones, C., and J. Lawton. 1995. Linking species and ecosystems. Chapman Hall, New York, New York, USA.

Keller, A. B., S. C. Reed, A. R. Townsend, and C. C. Cleveland. 2013. Effects of canopy tree species on belowground biogeochemistry in a lowland wet tropical forest. Soil Biology and Biogeochemistry 58:61-69.

Lodge, D. J., W. H. McDowell, J. Macy, S. K. Ward, R. Leisso, K. Claudio-Campos, and K. Kuhnert. 2008. Distribution and role of mat-forming saprobic basidiomycetes in a tropical forest. British Mycological Society Symposia Series 28:197209.

Lodge, D. J., F. N. Scatena, C. E. Asbury, and M. J. Sanchez. 1991. Fine litterfall and related nutrient inputs resulting from hurricane Hugo in subtropical wet and lower montane rainforests of Puerto Rico. Biotropica 23:336-342.

Mage, S. M., and S. Porder. 2013. Parent material and topography determine soil phosphorus status in the Luquillo Mountains of Puerto Rico. Ecosystems 16:284-294.

Marschner, H. 1999. Mineral nutrition of higher plants. Academic Press, London, UK.

Molofsky, J., and C. K. Augspurger. 1992. The effect of leaf litter on early seedling establishment in a tropical forest. Ecology 73:68-77.

Muscarella, R., M. Uriarte, J. Forero-Montaña, L. S. Comita, N. G. Swenson, J. Thompson, C. Nytch, I. Jonckheere, and J. K. Zimmerman. 2013. Exploring the mechanisms behind life history tradeoffs during the seed-to-seedling transition for tropical trees and lianas. Journal of Ecology 101:171-182.

Naeem, S. 2002. Ecosystem consequences of biodiversity loss: the evolution of a paradigm. Ecology 83:1537-1552.

Ostertag, R., E. Marín-Spiotta, W. Silver, and J. Schulten. 2008. Litterfall and decomposition in relation to soil carbon pools along a secondary forest chronosequence in Puerto Rico. Ecosystems 11:701-714.

Pastor, J., J. D. Aber, C. A. McClaugherty, and J. M. Melillo. 1984. Aboveground production and $\mathrm{N}$ and $\mathrm{P}$ cycling along a nitrogen mineralization gradient on Blackhawk Island, Wisconsin. Ecology 65:256-268.

Pèrez-Harguindeguy, N., S. Diaz, J. H. C. Cornelissen, F. Vendramini, M. Cabido, and A. Castellanos. 2000. Chemistry and toughness predict litter decomposition rates over a wide spectrum of functional types and taxa in central Argentina. Plant and Soil 218:21-30.

Pyke, D. A., and S. Archer. 1991. Plant-plant interactions affecting plant establishment and persistence on revegetated rangeland. Journal of Range Management 44:550-557.

$\mathrm{R}$ Core Team. 2013. R: a language and environment for statistical computing. R Foundation for Statistical Computing, Vienna, Austria.

Reed, S. C., C. C. Cleveland, and A. R. Townsend. 2008. Tree species control rates of free-living nitrogen fixation in a tropical rain forest. Ecology 89:2924-2934.

Reich, P. B., M. B. Walters, and D. S. Ellsworth. 1992. Leaf life span in relation to leaf, plant, and stand characteristics among diverse ecosystems. Ecological Monographs 62:365392.

Ribbens, E., J. A. Silander, and S. W. Pacala. 1994. Seedling recruitment in forests: calibrating models to predict patterns of tree seedling dispersion. Ecology 75:1794-1806.

Scott, N., and D. Binkley. 1997. Litter quality and annual net N mineralization: comparisons across sites and species. Oecologia 111:151-159.

Soil Survey Staff. 1995. Order 1 Soil Survey of the Luquillo Long-Term Ecological Research Grid, Puerto Rico. U.S. Department of Agriculture, Natural Resources Conservation Service, Lincoln, Nebraska, USA.

Staelens, J., L. Nachtergale, and S. Luyssaert. 2004. Predicting the spatial distribution of leaf litterfall in a mixed deciduous forest. Forest Ecology and Management 50:836-847.

Thompson, J., N. Brokaw, J. K. Zimmerman, R. B. Waide, E. M. Everham III, D. J. Lodge, C. M. Taylor, D. GarcíaMontiel, and M. Fluet. 2002. Land use history, environment, and tree composition in a tropical forest. Ecological Applications 12:1344-1363.

Tiessen, H., E. Cuevas, and P. Chacon. 1994. The role of soil organic matter in sustaining soil fertility. Nature 371:783785 .

Townsend, A. R., G. P. Asner, and C. C. Cleveland. 2008. The biogeochemical heterogeneity of tropical forests. Trends in Ecology and Evolution 23:424-431.

Uriarte, M., C. D. Canham, J. Thompson, and J. K. Zimmerman. 2009. Understanding natural disturbance and human land use as determinants of tree community dynamics in a subtropical wet forest: results from a forest simulator. Ecological Monographs 79:423-443.

Van Haren, J. L. M., R. C. De Oliveira, N. Restrepo-Coupe, L. Hutyra, P. B. De Camargo, M. Keller, and S. R. Saleska. 2010. Do plant species influence soil $\mathrm{CO}_{2}$ and $\mathrm{N}_{2} \mathrm{O}$ fluxes in a diverse tropical forest? Journal of Geophysical Research 115:G03010.

van Schaik, C. P., J. W. Terborgh, and S. J. Wright. 1993. The phenology of tropical forest: adaptive significance and consequences for primary consumers. Annual Review of Ecology and Systematics 24:353-377.

Vazquez-Yanes, C., and A. Orozco-Segovia. 1992. Effects of litter from a tropical rainforest on tree seed germination and establishment under controlled conditions. Tree Physiology 11:391-400.

Vitousek, P. M. 1984. Litterfall, nutrient cycling, and nutrient limitation in tropical forests. Ecology 65:285-298.

Vogt, K. A., et al. 1996. Litter dynamics along stream, riparian and upslope areas following Hurricane Hugo, Luquillo Experimental Forest, Puerto Rico. Biotropica 28:458-470.

Walker, L. R., D. J. Lodge, S. M. Guzmán-Grajales, and N. Fetcher. 2003. Species-specific seedling responses to hurricane disturbance in a Puerto Rican rain forest. Biotropica 35:472-485.

Walsh, R. P. D. 1996. Climate. Pages 159-205 in P. W. Richards, editor. The tropical rainforest: an ecological study. Second edition. Cambridge University Press, Cambridge, UK.

Wardle, D. 2002. Communities and ecosystems: linking the aboveground and belowground components. Princeton University Press, Princeton, New Jersey, USA.

Weaver, P. L., R. A. Birdsey, and A. E. Lugo. 1987. Soil organic matter in secondary forests in Puerto Rico. Biotropica 19:17-23.

White, A. F., A. E. Blum, M. S. Schulz, D. V. Vivit, D. A. Stonestrom, M. Larsen, S. F. Murphy, and D. Eberl. 1998. Chemical weathering in a tropical watershed, Luquillo Mountains, Puerto Rico: I. Long-term versus short-term weathering fluxes. Geochim Cosmochim Acta 62:209-226.

Wieder, W. R., C. C. Cleveland, and A. R. Townsend. 2008. Tropical tree species composition affects the oxidation of 
dissolved organic matter from litter. Biogeochemistry 88:127-138.

Xuluc-Tolosa, F. J., H. F. M. Vester, N. Ramırez-Marcial, J. Castellanos-Albores, and D. Lawrence. 2003. Leaf litter decomposition of tree species in three successional phases of tropical dry secondary forest in Campeche, Mexico. Forest Ecology and Management 174:401-412.

Zalamea, M., and G. González. 2008. Leaf fall phenology in a subtropical wet forest in Puerto Rico: from species to community patterns. Biotropica 40:295-304.

Zimmerman, J. K., E. M. Everham, R. B. Waide, D. J. Lodge, C. M. Taylor, and N. V. L. Brokaw. 1994. Responses of tree species to hurricane winds in subtropical wet forest in Puerto-
Rico-implications for tropical tree life-histories. Journal of Ecology 82:911-922.

Zimmerman, J. K., W. M. Pulliam, D. J. Lodge, V. Quinonesorfila, N. Fetcher, S. Guzman-Grajales, J. A. Parrotta, C. E. Asbury, L. R. Walker, and R. B. Waide. 1995. Nitrogen immobilization by decomposing woody debris and the recovery of tropical wet forest from hurricane damage. Oikos 72:314-322.

Zinke, P. J. 1962. The pattern of influence of individual forest trees on soil properties. Ecology 43:130-133.

Zou, X., C. P. Zucca, R. B. Waide, and W. H. McDowell. 1995. Long-term influence of deforestation on tree species composition and litter dynamics of a tropical rain forest in Puerto Rico. Forest Ecology and Management 78:147-157.

\section{Supplemental Material}

\section{Ecological Archives}

Appendices A and B are available online: http://dx.doi.org/10.1890/15-0112.1.sm 